\title{
Toxicity of Photobacterium damselae subsp. damselae strains isolated from new cultured marine fish
}

\author{
Alejandro Labella ${ }^{1}$, Nuria Sanchez-Montes ${ }^{1}$, Concepcion Berbel ${ }^{2}$, Manuel Aparicio ${ }^{2}$, \\ Dolores Castro ${ }^{1}$, Manuel Manchado ${ }^{2}$, Juan J. Borrego ${ }^{1, *}$ \\ ${ }^{1}$ Department of Microbiology, Faculty of Sciences, University of Malaga, 29071 Malaga, Spain \\ ${ }^{2}$ IFAPA Centro El Toruño, Junta de Andalucia, Puerto de Santa Maria, 11500 Cadiz, Spain
}

\begin{abstract}
The in vivo and in vitro toxicity of bacterial cells and their extracellular products (ECPs) from 16 strains of Photobacterium damselae subsp. damselae isolated from 7 epizootic outbreaks were evaluated. On the basis of their $50 \%$ lethal dose $\left(\mathrm{LD}_{50}\right)$ values (about $1 \times 10^{5} \mathrm{CFU}$ ), these strains may be considered as moderately virulent. However, their ECPs were strongly lethal for redbanded seabream Pagrus auriga causing fish death within $2 \mathrm{~h}$ post-inoculation (protein concentration ranged between 2.1 and $6.41 \mathrm{\mu g} \mathrm{g}^{-1}$ fish). The bacterial ECPs tested exhibited several enzymatic activities, such as amylase, lipase, phospholipase, alkaline phosphatase, esterase-lipase, acid phosphatase, and $\beta$-glucosaminidase. These ECPs displayed a strong cytotoxic effect on 4 fish and 2 mammalian cell lines, although this activity disappeared when ECPs were heated at $100^{\circ} \mathrm{C}$. The virulence of the strains tested could not be related to the hemolytic activity or to the production of the toxin damselysin. Therefore, another unknown type of toxin could play an important role in the virulence mechanisms of this bacterial pathogen.
\end{abstract}

KEY WORDS: Toxicity $\cdot$ ECP $\cdot$ Photobacterium damselae subsp. damselae $\cdot$ Cultured marine fish

\section{INTRODUCTION}

Photobacterium damselae subsp. damselae is a halophilic bacterium associated with several diseases affecting both wild and cultured fish species (Fouz et al. 1991, 1992, Vera et al. 1991) and mammals, including humans (Clarridge \& Zighelboim-Daum 1985, Coffey et al. 1986, Buck et al. 1991, Yamane et al. 2004). Epizootic outbreaks of this bacterial pathogen have been associated with immunocompromised or stressed fish by overcrowding (Thune et al. 1993, GarciaRosado et al. 2007). Symptoms of these bacterial pathologies are not specific, including hemorrhagic septicemia with extensive skin lesions and focal necrosis of the liver, spleen, kidney, and other tissues (Hjeltnes \& Roberts 1993).

Several new marine species are being evaluated as potential candidates for aquaculture production. In southern Europe, studies on reproductive cycles, nutri- tion, growth, and immune system of species such as redbanded seabream Pagrus auriga, white seabream Diplodus sargus, and meagre Argyrosomus regius are ongoing (Cardenas \& Manchado 2008, Martin-Antonio et al. 2009). However, the intensive culture of these fish species and others has favored the appearance of several outbreaks with moderate mortality involving Photobacterium damselae subsp. damselae (Labella et al. 2006, Garcia-Rosado et al. 2007, KanchanopasBarnette et al. 2009).

Several virulence factors are involved in the pathogenesis of Vibrio and Photobacterium genera (Norqvist et al. 1990, David et al. 1992, Toranzo \& Barja 1993, Magariños et al. 1994, Bakopoulos et al. 1997, Perez et al. 1998, Farto et al. 2002, 2006, Ishihara et al. 2002, Wang et al. 2007). In the case of $P$. damselae subsp. damselae only an extracellular cytolytic toxin, named damselysin, which is a phospholipase-D active against the sphingomyelin of the sheep erythrocyte mem- 
brane, has been described (Kreger 1984, Kothary \& Kreger 1985, Kreger et al. 1987). In addition, a relationship between the degree of virulence and the hemolytic activity has been demonstrated in P. damselae subsp. damselae strains isolated from fish (Fouz et al. 1993). However, Cutter \& Kreger (1990) found that not all the $P$. damselae subsp. damselae strains presented the damselysin gene $(d l y)$, but only those strains showing intense hemolytic activity. A further study demonstrated that the presence of this gene was not correlated to the virulence in mice and fish of 17 P. damselae subsp. damselae strains isolated from different sources (Osorio et al. 2000).

The extracellular products (ECPs) are produced by bacterial pathogens to facilitate the uptake of nutrients from the surrounding environment, and/or for the successful penetration and survival of pathogens inside the host (Bakopoulos et al. 2003). However, the role of ECPs in the pathogenesis of Photobacterium damselae subsp. damselae in fish is poorly known, which is a considerable disadvantage for the development of vaccines and vaccine strategies, since it has been suggested that the ECP components are major antigenic compounds of several vaccine formulations (Collado et al. 2000, Bakopoulos et al. 2004).

The aim of this study was to determine the toxicity of different Photobacterium damselae subsp. damselae strains isolated from cultured diseased fish. For this purpose, we performed in vivo and in vitro assays using bacterial cultures and their ECPs. In addition, the enzymatic activities of the ECPs and their cytotoxicity in fish and mammalian cell lines were compared.

\section{MATERIALS AND METHODS}

Bacterial strains. In this study, 16 Photobacterium damselae subsp. damselae strains associated with epizootic outbreaks affecting various cultured marine fish species (Table 1) were used. All the isolates were phenotypically and genotypically characterized as previously described (Labella et al. 2006, 2009, Kanchanopas-Barnette et al. 2009). P. damselae subsp. damselae strain ATCC $33539^{\mathrm{T}}$, isolated from damselfish, was used for comparative purposes.

Strains were routinely cultured on tryptic soy agar or broth (TSA or TSB) (Difco Lab) supplemented with $1.5 \%(\mathrm{w} / \mathrm{v}) \mathrm{NaCl}$ (TSAs or TSBs, respectively), and incubated at $22^{\circ} \mathrm{C}$ for 2 to $5 \mathrm{~d}$. Stock cultures were stored frozen at $-80^{\circ} \mathrm{C}$ in TSBs with $15 \%$ (v/v) glycerol.

ECPs extraction. Bacterial ECPs were obtained by the cellophane plate technique (Liu 1957) by spreading $3 \mathrm{ml}$ of a $24 \mathrm{~h}$ broth culture of each strain over sterilized cellophane sheets placed on TSAs plates. After incubation for $48 \mathrm{~h}$ at $22^{\circ} \mathrm{C}$, bacterial cells were washed off the cellophane sheets with phosphatebuffered saline (PBS) at $\mathrm{pH}$ 7.0. The bacterial suspensions were centrifuged at $13000 \times g$ for $20 \mathrm{~min}$ at $4^{\circ} \mathrm{C}$, and the respective supernatants were filtered through $0.45 \mu \mathrm{m}$ pore-size membrane filters. All the ECP samples were stored at $-20^{\circ} \mathrm{C}$ until used. The protein concentration of the ECPs was spectrophotometrically determined by using bicinchoninic acid (SigmaAldrich) and bovine serum albumin (Sigma-Aldrich) as standard. To evaluate the total proteolytic activity present in the ECP samples, a multiprotein substrate (Azocoll; Sigma-Aldrich) was used following the

Table 1. Source of the Photobacterium damselae subsp. damselae strains and protein content and total proteolytic activity of their extracellular products. ATCC: American type culture collection

\begin{tabular}{|c|c|c|c|c|c|}
\hline Strain & Source & $\begin{array}{l}\text { Isolation } \\
\text { organ }\end{array}$ & $\begin{array}{l}\text { Outbreak } \\
\text { date }\end{array}$ & $\begin{array}{l}\text { Proteins } \\
\left(\mu \mathrm{ml}^{-1}\right)\end{array}$ & $\begin{array}{c}\text { Proteolytic } \\
\text { activity }\left(\mathrm{U} \mathrm{ml}^{-1}\right)\end{array}$ \\
\hline $203 \mathrm{H}$ & Redbanded seabream Pagrus auriga & Liver & Winter 2003 & 910.3 & 0.23 \\
\hline $401 \mathrm{H}$ & Redbanded seabream $P$. auriga & Liver & Spring 2004 & 594.16 & 0.04 \\
\hline $402 \mathrm{O}$ & Redbanded seabream $P$. auriga & Eye & Autumn 2004 & 412.50 & 0.59 \\
\hline 403D1 & Redbanded seabream $P$. auriga & Intestine & Autumn 2004 & 533.05 & 0.16 \\
\hline $412 \mathrm{~B}$ & Redbanded seabream $P$. auriga & Spleen & Autumn 2004 & 473.05 & $<0.01$ \\
\hline $9401 \mathrm{H}$ & Redbanded seabream $P$. auriga & Liver & Summer 2004 & 877.08 & $<0.01$ \\
\hline $501 \mathrm{H}$ & Redbanded seabream $P$. auriga & Liver & Summer 2005 & 613.61 & $<0.01$ \\
\hline $501 \mathrm{R}$ & Redbanded seabream $P$. auriga & Kidney & Summer 2005 & 346.38 & $<0.01$ \\
\hline $501 \mathrm{~B}$ & Redbanded seabream $P$. auriga & Spleen & Summer 2005 & 218.05 & $<0.01$ \\
\hline $601 \mathrm{R}$ & Redbanded seabream $P$. auriga & Kidney & Summer 2006 & 414.72 & 0.05 \\
\hline $602 \mathrm{R}$ & Redbanded seabream $P$. auriga & Kidney & Summer 2006 & 347.50 & $<0.01$ \\
\hline D408U & Gilt-head seabream Sparus aurata & Ulcers & Autumn 2004 & 835.27 & 0.93 \\
\hline Lb501R & European seabass Dicentrarchus labrax & Kidney & Summer 2005 & 564.72 & 0.12 \\
\hline S503C & White seabream Diplodus sargus & Brain & Summer 2005 & 554.72 & $<0.01$ \\
\hline C601R1 & Meagre Argyrosomus regius & Kidney & Summer 2006 & 774.16 & $<0.01$ \\
\hline LCA240907 & Barramundi Lates calcarifer & Liver & Autumn 2007 & 1282.39 & 0.38 \\
\hline ATCC $33539^{\mathrm{T}}$ & Damselfish Chromis punctipinnis & & - & 420.00 & 0.02 \\
\hline
\end{tabular}


manufacturer's instructions. An absorbance reading of 1.0 at $520 \mathrm{~nm}$, after a $30 \mathrm{~min}$ assay at $37^{\circ} \mathrm{C}$, was defined as one unit of protease activity.

Determination of enzymatic activities. The enzymatic activities presented in the ECPs and in bacterial cultures were evaluated using the API ZYM system (bioMérieux). Other enzymatic activities, such as caseinase, gelatinase, amylase, phospholipase, and lipase, were determined in plates by a diffusion method. Plate dishes of saline basal nutrient agar (Difco) $(1.5 \% \mathrm{NaCl}, \mathrm{w} / \mathrm{v})$ were supplemented with $1 \%(\mathrm{w} / \mathrm{v})$ sodium caseinate (Difco), $1 \%(\mathrm{w} / \mathrm{v})$ gelatin (Oxoid), $0.4 \%$ (w/v) starch (Difco), $2 \%$ (v/v) egg yolk emulsion (Sigma-Aldrich) and 1\% (v/v) Tween20/Tween-80 (Sigma-Aldrich), respectively. In addition, commercial deoxyribonuclease test medium (Biolife) was used for the DNase test. The production of hemolysins was assayed on Mueller-Hinton agar (Oxoid) supplemented with $5 \%$ (v/v) sheep, calf, or redbanded seabream blood. In all the tests, aliquots of $5 \mu \mathrm{l}$ of each ECP or exponential growth bacterial cultures in TSBs were placed on the plates and incubated at $22^{\circ} \mathrm{C}$ for 24 to $48 \mathrm{~h}$, following the methodology described by Balebona et al. (1998a). To determine the heat stability, all the enzymatic activities were also tested after treatment of ECP samples at $100^{\circ} \mathrm{C}$ for $10 \mathrm{~min}$.

Assessment of in vivo toxicity of Photobacterium damselae subsp. damselae and their ECPs. The determination of the $50 \%$ lethal dose $\left(\mathrm{LD}_{50}\right)$ was conducted by intraperitoneal (IP) inoculation of redbanded seabream specimens (5 to $10 \mathrm{~g}$ in weight). Groups of 20 fish were inoculated with washed bacterial cells in PBS at doses ranging from $10^{2}$ to $10^{8} \mathrm{CFUs}$ per fish, held at $22^{\circ} \mathrm{C}$ for $15 \mathrm{~d}$, and observed daily for pathological signs. Groups of control fish were inoculated with $0.1 \mathrm{ml}$ of sterile PBS ( $\mathrm{pH} 7.4$ ). Mortalities were considered to be due to the inoculated bacterial strain only when it was recovered from internal organs as a pure culture. The $\mathrm{LD}_{50}$ was determined by the Reed \& Muench (1938) method.

The toxicity of the ECPs of the Photobacterium damselae subsp. damselae strains was evaluated by IP inoculation of $0.1 \mathrm{ml}$ of each ECP sample in groups of 20 redbanded seabream specimens (5 to $10 \mathrm{~g}$ in weight). The mortality rate of each group was monitored over a $7 \mathrm{~d}$ period. Sets of animals inoculated with sterile PBS ( $\mathrm{pH} 7.4$ ) were included in the trials as negative controls. ECPs heated at $100^{\circ} \mathrm{C}$ for $10 \mathrm{~min}$ were also assayed in parallel.

Cytotoxic activity of the ECPs. Cytotoxicity assays were basically carried out as described by Wang et al. (1998) on mammalian and fish cell lines. Two different mammalian cell lines were employed: NIH/3T3, a murine fibroblastic cell line, and HT-1080, a human epithelial cell line. Cells were cultured and maintained using Dulbecco's modified Eagle's medium (HyClone Laboratories) supplemented with $4 \mathrm{mM}$ L-glutamine (Sigma-Aldrich), bovine calf serum (Gibco) to a final concentration of $10 \%(\mathrm{v} / \mathrm{v})$ and $1 \%(\mathrm{v} / \mathrm{v})$ penicillinstreptomycin solution (Gibco). Cell cultures were incubated in $5 \% \mathrm{CO}_{2}$ at $37^{\circ} \mathrm{C}$ and $95 \%$ humidity. Four different fish cell lines were tested: SAF-1, a fibroblastic cell line from gilt-head seabream Sparus aurata (Bejar et al. 1997); BF-2, a fibroblastic cell line from bluegill fry Lepomis macrochirus; CHSE-214, an epithelial cell line from Chinook salmon Oncorhynchus tshawytscha; and SSN-1, an epithelial cell line derived from striped-snakehead fish Ophicephalus striatus. Fish cells were cultured and maintained using Leibovitz medium (L-15; Gibco), supplemented with $2 \%$ (v/v) L-glutamine solution, $1 \%$ (v/v) penicillin-streptomycin solution and $10 \%(\mathrm{v} / \mathrm{v})$ foetal bovine serum (Cambrex). Two different incubation temperatures were used for the maintenance and growth of the cell cultures: $25^{\circ} \mathrm{C}$ for SAF-1, BF-2, and SSN-1 cell lines, and $20^{\circ} \mathrm{C}$ for the CHSE-214 cell line.

For the cytotoxicity assay, 12-well plates were prepared for each cell line and bacterial strain. Cell cultures were inoculated with $0.1 \mathrm{ml}$ of the ECP or ECP heated $\left(100^{\circ} \mathrm{C}, 10 \mathrm{~min}\right)$ samples, PBS $(\mathrm{pH} 7.4)$ being used as negative control. Each experimental condition was assayed in triplicate. The development of cytotoxic effects was observed at 6, 24 and $48 \mathrm{~h}$ post-inoculation using a phase-contrast inverted microscope (Nikon) at 200× magnification.

Detection of phospholipase-D (dly) gene. Bacterial cells from a $24 \mathrm{~h}$ culture in TSBs were resuspended in $500 \mu \mathrm{l}$ of TES buffer (Sigma-Aldrich) supplemented with $5 \mu \mathrm{l}$ of lysozyme (10 $\mathrm{mg} \mathrm{ml}^{-1}$ stock solution) (Sigma-Aldrich) and incubated at $37^{\circ} \mathrm{C}$ for $30 \mathrm{~min}$. Then, $5 \mu \mathrm{l}$ each of Proteinase $\mathrm{K}\left(10 \mathrm{mg} \mathrm{ml}^{-1}\right.$ stock solution; Sigma-Aldrich) and RNase $\left(10 \mathrm{mg} \mathrm{ml}^{-1}\right.$ stock solution; Sigma-Aldrich) were added, and the solution was incubated for $1 \mathrm{~h}$ at $65^{\circ} \mathrm{C}$. After addition of $50 \mu \mathrm{l}$ of $20 \%$ (w/v) SDS (Sigma-Aldrich), tubes were returned immediately to the $65^{\circ} \mathrm{C}$ water bath for a further 10 min. After cell lysis, a phenol/chloroform extraction was performed. DNA was precipitated with cold ethanol $\left(-20^{\circ} \mathrm{C}\right)$, and resuspended in $50 \mu \mathrm{l}$ of sterile distilled water. DNA concentration was spectrophotometrically determined at $260 \mathrm{~nm}$.

Two primer sets designed for the amplification of the complete dly gene (dly-1f/dly-2r) and a fragment of $567 \mathrm{bp}$ (dly-5'f/dly-3'r) were used, according to Osorio et al. (2000). PCR amplifications were performed in a DNA thermocycler (Eppendorf Iberica). A typical reaction mixture $(100 \mu \mathrm{l})$ consisted of $0.5 \mu \mathrm{g}$ of each primer, 2 U of Taq polymerase (Perkin Elmer Tech. Center), Taq polymerase buffer (Perkin Elmer), $2 \mathrm{mM} \mathrm{MgCl}_{2}$, 
$200 \mu \mathrm{M}$ of each deoxynucleoside triphosphate, and $100 \mathrm{ng}$ of DNA. The amplification conditions for the complete $d l y$ gene were $95^{\circ} \mathrm{C}$ for 4 min followed by 30 cycles at $95^{\circ} \mathrm{C}$ for $1 \mathrm{~min}, 55^{\circ} \mathrm{C}$ for $1 \mathrm{~min}$, and $72^{\circ} \mathrm{C}$ for $3 \mathrm{~min}$. A final extension step of $10 \mathrm{~min}$ at $72^{\circ} \mathrm{C}$ was carried out. For the $567 \mathrm{bp}$ fragment, the amplification conditions were $95^{\circ} \mathrm{C}$ for $4 \mathrm{~min}, 30$ cycles at $95^{\circ} \mathrm{C}$ for $1 \mathrm{~min}, 55^{\circ} \mathrm{C}$ for $1 \mathrm{~min}$, and $72^{\circ} \mathrm{C}$ for $40 \mathrm{~s}$, and $72^{\circ} \mathrm{C}$ for $5 \mathrm{~min}$. Amplification products were analysed on $1 \%$ (w/v) agarose gels with TAE (0.04 M Tris-acetate, 1 mM EDTA) electrophoresis buffer, and were visualized on a UV transilluminator after staining with ethidium bromide. A high molecular weight DNA marker (Roche Diagnostics) was included in all the gels. DNA from Photobacterium damselae subsp. piscicida ATCC $17911^{\mathrm{T}}$ was used as negative control.

\section{RESULTS}

\section{In vivo toxicity and enzymatic activities of ECPs}

The extracellular products of the Photobacterium damselae subsp. damselae strains tested were strongly lethal for redbanded seabream, resulting in death between 2 and $4 \mathrm{~h}$ after inoculation. The main clinical signs and gross changes were lethargy, increase in the respiratory frequency and mucus production. The inoculated fish became excited and disorientated, bumping into the aquarium walls. Internally, presence of ascitic liquid, hemorrhagic and enlarged liver, and hemorrhages in the abdominal cavity were the main signs. In contrast, ECP from the strain $9401 \mathrm{H}$ and heated ECP samples $\left(100^{\circ} \mathrm{C}\right.$ for $\left.10 \mathrm{~min}\right)$ of all the strains tested did not produce toxic effects in fish after a $7 \mathrm{~d}$ post-inoculation period, although fish survivors exhibited abnormal enlarged spleen and kidney.

The characterization of ECPs from Photobacterium damselae subsp. damselae was performed studying their enzymatic activities. All ECP samples showed remarkable content of protein (218 to $1282 \mu \mathrm{g} \mathrm{ml}^{-1}$ ), although the total proteolytic activity, as determined by using azocoll, was very low (<10 $\mathrm{U} \mathrm{ml}^{-1}$ ) (Table 1). Furthermore, specific proteolytic enzymes, such as caseinase or gelatinase, were not detected, except for the strain 412B, which exhibited gelatinase activity. Nevertheless, ECP samples exhibited other enzymatic activities such as amylase, lipase (Tween-20), and phospholipase. None of the ECP samples analyzed was able to hydrolyze DNA or Tween-80 (Table 2).

The enzymatic activities of the ECP samples were also evaluated by using the API ZYM system. ECPs of Photobacterium damselae subsp. damselae strains tested were positive for alkaline phosphatase, esterase-lipase, acid phosphatase, and N-acetyl- $\beta$-glucosaminidase activities, being negative for the presence of $\beta$-glucuronidase. Variable results were obtained with the remaining enzymatic activities (Table 3).

All enzymatic activities of Photobacterium damselae subsp. damselae ECPs were lost by heating of the samples, except the phospholipase activity of strains $402 \mathrm{O}$ and ATCC $33539^{\mathrm{T}}$.

Table 2. Enzymatic activities of extracellular products (ECPs) and bacterial cells of Photobacterium damselae subsp. damselae strains using plate tests. +: positive result; -: negative result. T20: Tween-20; T80: Tween-80

\begin{tabular}{|c|c|c|c|c|c|c|c|c|c|}
\hline \multirow{2}{*}{ Strain } & \multirow[b]{2}{*}{ Caseinase } & \multirow[b]{2}{*}{ Gelatinase } & \multirow[b]{2}{*}{ Amylase } & \multirow{2}{*}{$\begin{array}{l}\text { Activ } \\
\text { DNase }\end{array}$} & \multirow{2}{*}{$\begin{array}{c}y \text { in ECP } \\
\text { Lipase } \\
\text { (T20) }\end{array}$} & \multirow{2}{*}{$\begin{array}{c}\text { acterial } \\
\text { Lipase } \\
\text { (T80) }\end{array}$} & \multirow{2}{*}{$\begin{array}{l}\text { ells } \\
\text { Phospholipase }\end{array}$} & \multirow[b]{2}{*}{$\begin{array}{l}\text { Hemolysis } \\
\text { (sheep } \\
\text { and calf) }\end{array}$} & \multirow[b]{2}{*}{$\begin{array}{c}\text { Hemolysis } \\
\text { (redbanded } \\
\text { seabream) }\end{array}$} \\
\hline & & & & & & & & & \\
\hline $203 \mathrm{H}$ & $-1-$ & $-1-$ & $+/+$ & $-1-$ & $+/+$ & $-1-$ & $-1+$ & $-1+$ & $-1-$ \\
\hline $401 \mathrm{H}$ & $-1-$ & $-1-$ & $-1-$ & $-1-$ & $+/+$ & $-1-$ & $+/+$ & $-1-$ & $-1+$ \\
\hline $402 \mathrm{O}$ & $-/-$ & $-1-$ & $-/-$ & $-1-$ & $+/+$ & $-1-$ & $+/+$ & $+/+$ & $+/+$ \\
\hline 403D1 & $-/-$ & $-1-$ & $-/-$ & $-1-$ & $+/+$ & $-1-$ & $+/+$ & $-1+$ & $-1+$ \\
\hline 412B & $-/-$ & $+/+$ & $-/-$ & $-1-$ & $+/+$ & $-1-$ & $-1-$ & $-1-$ & $-1+$ \\
\hline $9401 \mathrm{H}$ & $-/-$ & $-1-$ & $+/+$ & $-1-$ & $-1-$ & $-1-$ & $-/+$ & $-1+$ & $-/+$ \\
\hline $501 \mathrm{H}$ & $-/-$ & $-1-$ & $-1-$ & $-1-$ & $-1-$ & $-1-$ & $-/+$ & $-/+$ & $-/+$ \\
\hline $501 \mathrm{R}$ & $-/-$ & $-1-$ & $-1-$ & $-1-$ & $+/+$ & $-1-$ & $+/+$ & $-/+$ & $-/+$ \\
\hline $501 \mathrm{~B}$ & $-1-$ & $-1-$ & $-1-$ & $-1-$ & $-1-$ & $-1-$ & $+/+$ & $-/+$ & $-/+$ \\
\hline $601 R$ & $-1-$ & $-1-$ & $+/+$ & $-1-$ & $-1-$ & $-1-$ & $+/+$ & $-/+$ & $-1+$ \\
\hline $602 \mathrm{R}$ & $-1-$ & $-1-$ & $+/+$ & $-1-$ & $-1-$ & $-1-$ & $+/+$ & $-/+$ & $-1+$ \\
\hline D408U & $-/-$ & $-1-$ & $-/-$ & $-1-$ & $+/+$ & $-1-$ & $+/+$ & $-/+$ & $-1+$ \\
\hline Lb501R & $-/-$ & $-1-$ & $-1-$ & $-1-$ & $+/+$ & $-1-$ & $+/+$ & $-/+$ & $-1-$ \\
\hline S503C & $-/-$ & $-1-$ & $-1-$ & $-1-$ & $+/+$ & $-1-$ & $+/+$ & $-/+$ & $-1-$ \\
\hline C601R1 & $-/-$ & $-1-$ & $-/-$ & $-1-$ & $+/+$ & $-1-$ & $+/+$ & $-/+$ & $-1+$ \\
\hline LCA240907 & $-/-$ & $-1-$ & $+/+$ & $-1-$ & $+/+$ & $-1-$ & $-/+$ & $-1+$ & $-1+$ \\
\hline ATCC $33539^{\mathrm{T}}$ & $-1-$ & $-1-$ & $+/+$ & $-1-$ & $+/+$ & $-1-$ & $+/+$ & $-1+$ & $-1+$ \\
\hline
\end{tabular}


Lethal dose and enzymatic activities of bacterial cultures

The $\mathrm{LD}_{50}$ obtained by IP inoculation of Photobacterium damselae subsp. damselae strains were very similar, with a mean value of about $1 \times 10^{5}$ $\mathrm{CFU}$, except for the strain $9401 \mathrm{H}$ with a value higher than $10^{8} \mathrm{CFU}$. According to Santos et al. (1988) criteria, these strains may be considered as moderately virulent, and non-virulent in the case of the strain $9401 \mathrm{H}$.

Similar to the results obtained for ECPs, the 17 strains tested did not present caseinase, gelatinase, DNase, and lipase (Tween-80) activities, except the strain 412B, which was gelatinase positive. Amylase and lipase (Tween-20) activities were recorded in 35.3 and $70.6 \%$, respectively of the Photobacterium damselae subsp. damselae strains tested. All P. damselae subsp. damselae strains displayed phospholipase activity, except the strain 412B (Table 2).

However, several differences were determined in the enzymatic activities presented in ECPs versus bacterial cells using the API ZYM system (Tables $3 \& 4$ ). Thus, the leucine arylaminidase activity was present in all bacterial cells tested whilst this enzymatic activity was absence or in low levels in their corresponding ECPs. Similarly, $\beta$-glucosidase activity was recorded in the bacterial cultures of 9 strains tested, but was absent in their ECPs, except for the strain LCA240907. For N-acetyl- $\beta$ glucosaminidase, higher levels of activity were obtained for the cells compared to their ECPs. In contrast, $\alpha$-chymotrypsin activity was recorded in ECPs of 11 strains tested, but was absent in their bacterial cells, except for the strain 412B.

\section{Cytotoxicity of ECPs using mammalian and fish cell lines}

The ECPs of Photobacterium damselae subsp. damselae strains isolated from different fish species were assayed to evaluate their in vitro toxicity using both mammalian and fish cell lines. The ECP samples tested displayed cytotoxic effects on all the cell lines used at $6 \mathrm{~h}$ post-inoculation, with a total destruction of the cell monolayers at $48 \mathrm{~h}$ post-inoculation, except for the strain $9401 \mathrm{H}$, which did not produce cytotoxic effects. The degenerative changes mainly consisted of the appearance of clusters of round cells and dendritic elongations (Fig. 1), and finally cell detachment. However, the ECPs heated at $100^{\circ} \mathrm{C}$ had no effects on the different cell lines used.

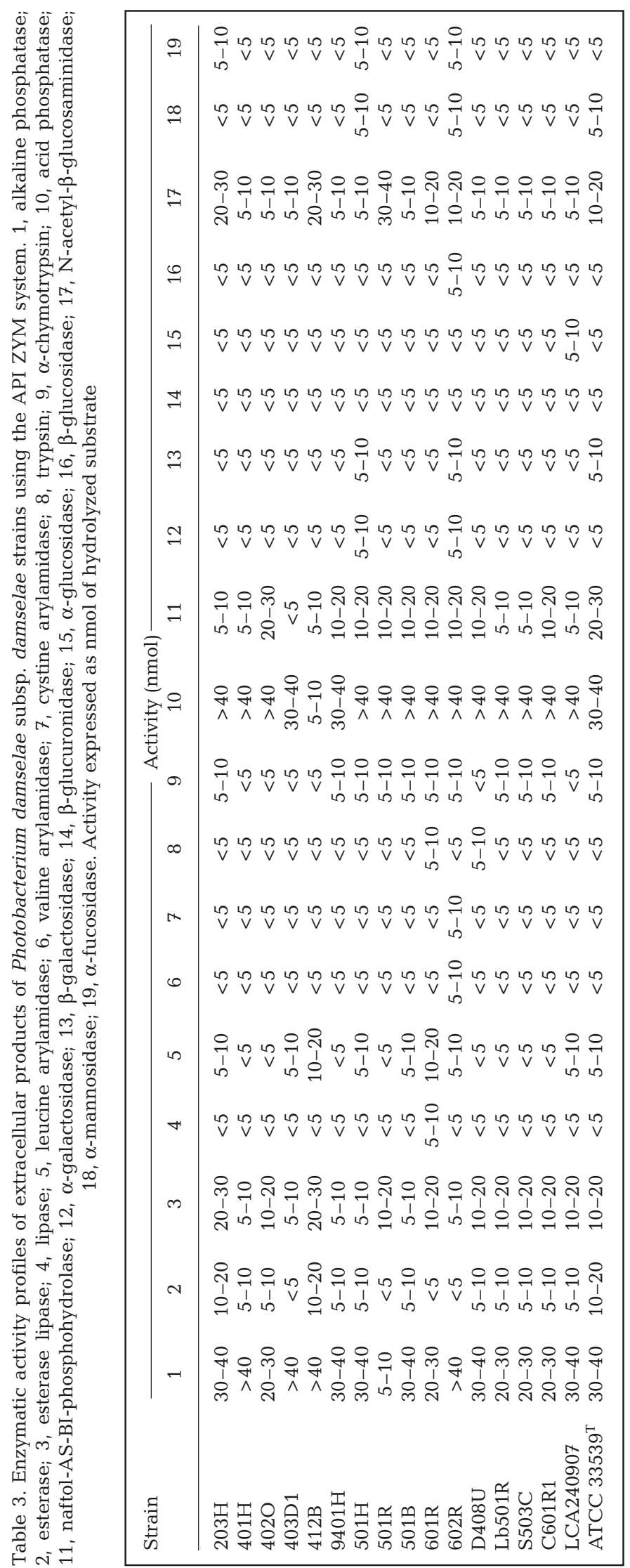




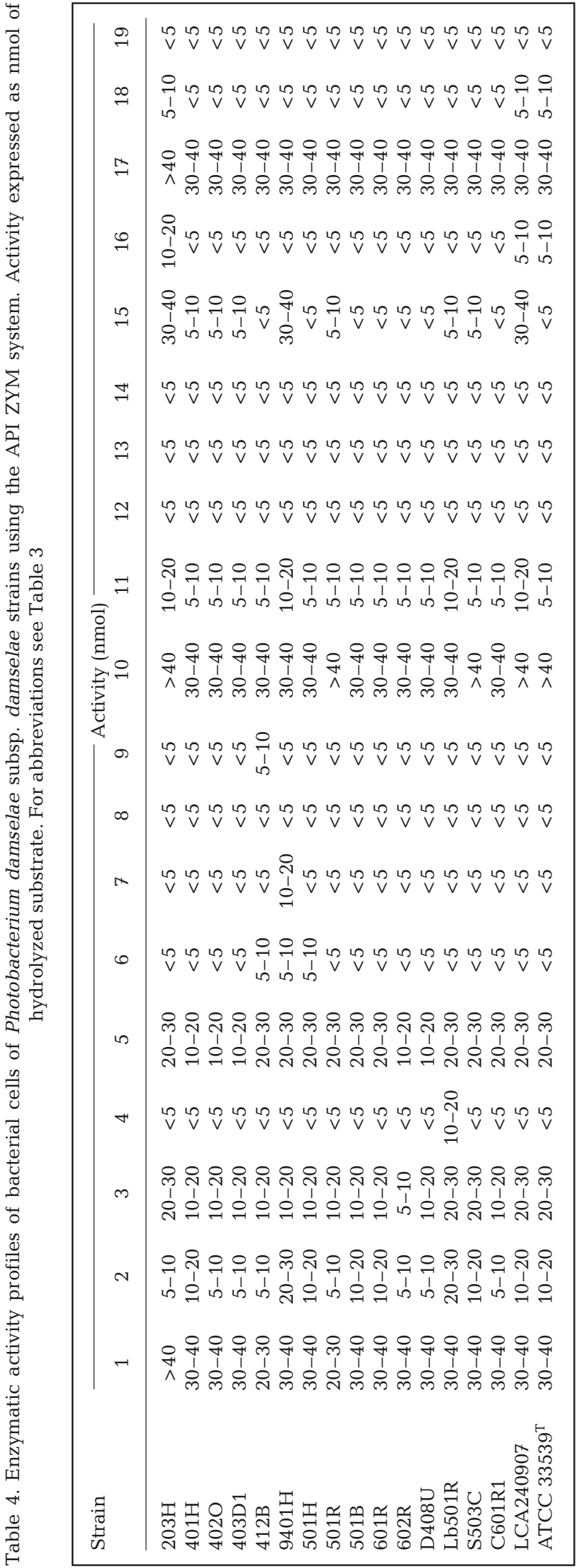

\section{Hemolysis and detection of the phospholipase-D gene}

The different strains of Photobacterium damselae subsp. damselae tested showed an evident hemolytic capacity on Mueller-Hinton plates supplemented with sheep, calf, and redbanded seabream blood, excepting for the strains $401 \mathrm{H}$ and 412B for sheep and calf blood, and 203H, Lb501R and S503C for fish blood (Table 2). The ECP samples produced no hemolysis for any of the strains tested, except in the case of the strain 402O, which produced hemolysis using all the erythrocyte types tested. The hemolytic activity of ECP of $402 \mathrm{O}$ strain was lost by heating at $100^{\circ} \mathrm{C}$ for $10 \mathrm{~min}$, which indicates the production of thermolabile hemolysins by this strain.

Only the strongly hemolytic strains (402O and ATCC $33539^{\mathrm{T}}$ ) showed the specific 567 bp PCR product corresponding to the phospholipase-D gene using the primers dly-5'f and dly-3'r (Fig. 2). The amplification of the complete gene using dly-1f and dly-2r primers failed for all the strains tested.

\section{DISCUSSION}

Photobacterium damselae subsp. damselae is recognized as an opportunistic pathogen for a wide variety of hosts, mainly fish, dolphins, and humans (Fujioka et al. 1988, Pedersen et al. 1997, Yamane et al. 2004), being the causative agent of hemorrhagic septicemia in several cultured fish species (Labella et al. 2006, Kanchanopas-Barnette et al. 2009). The continuous isolation of this bacterial pathogen from diseased specimens of newly cultured fish species (Table 1) reveals that the syndrome may well be an emerging disease in cultured marine fish in several geographical areas.

Photobacterium damselae subsp. damselae possesses a variety of virulence factors that affect both mammals and fish, provoking symptoms such as septicemia, hemorrhages, and massive ulcers and necrosis on the skin surface or in other tissues. These data suggest that several secreted ECPs of the pathogen may contribute to the bacterial growth inside the hosts (Sakai 1985) and induce an infection and disease. Main ECP components related to virulence include proteases, hemolysins, and siderophore-mediated iron sequestering systems (Balebona et al. 1998b, Rodkum et al. 2005, Wang et al. 2007). These mechanisms can provoke tissue destruction and hemorrhages, playing an important role in colonization, invasiveness, and dissemination within the host (Finkelstein et al. 1992, Silva et al. 2003).

In the present study, the pathogenicity of Photobacterium damselae subsp. damselae strains isolated from different outbreaks affecting newly cultured marine 

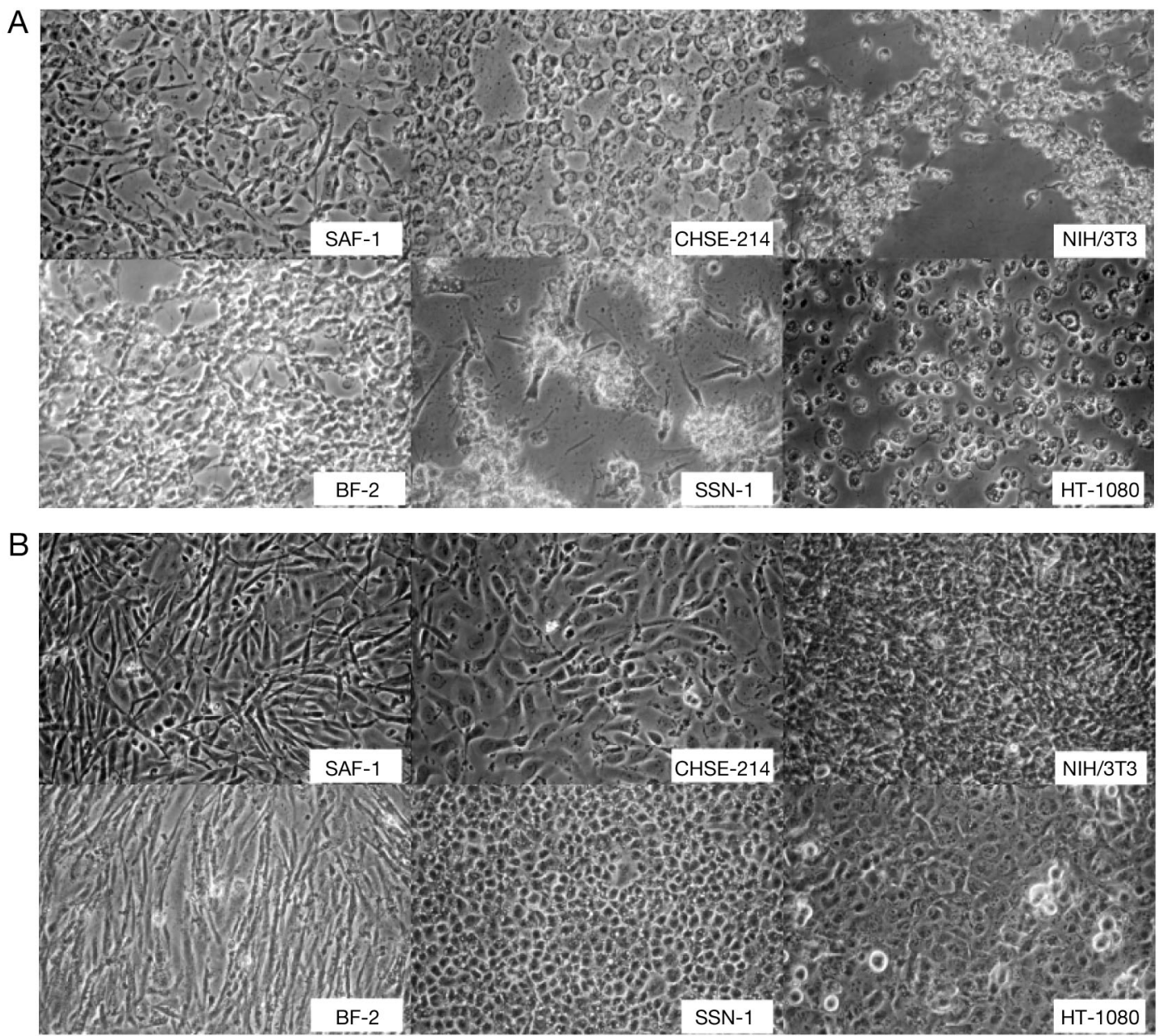

Fig. 1. Photobacterium damselae subsp. damselae extracellular product (ECP) cytotoxicity assay using mammalian and fish cell lines (see 'Materials and methods: Cytotoxic activity of the ECPs' for details). (A) Clusters of round cells and dendritic elongations produced by inoculation of ECP samples. (B) Inoculation of heated ECP samples produced no cytotoxic effects

fish have been evaluated. All the strains may be considered as moderately virulent according to Santos et al. (1988) criteria, with $\mathrm{LD}_{50}$ values about $1 \times 10^{5} \mathrm{CFU}$, with the exception of one non-virulent strain $\left(\mathrm{LD}_{50}>\right.$ $\left.10^{8} \mathrm{CFU}\right)$. The intraperitoneal inoculation of ECPs from the virulent strains was lethal for redbanded seabream at 2 to $4 \mathrm{~h}$ post-inoculation. Tissue damage was more severe than those observed after bacterial inoculation (data not shown). Similar results have been reported for Listonella (=Vibrio) anguillarum and P. damselae subsp. damselae in other fish species (Lamas et al. 1994, Fouz et al. 1995). The inoculation of heated ECPs to fish did not produce deaths, which suggests that the active fraction of the exotoxin present in the ECPs is

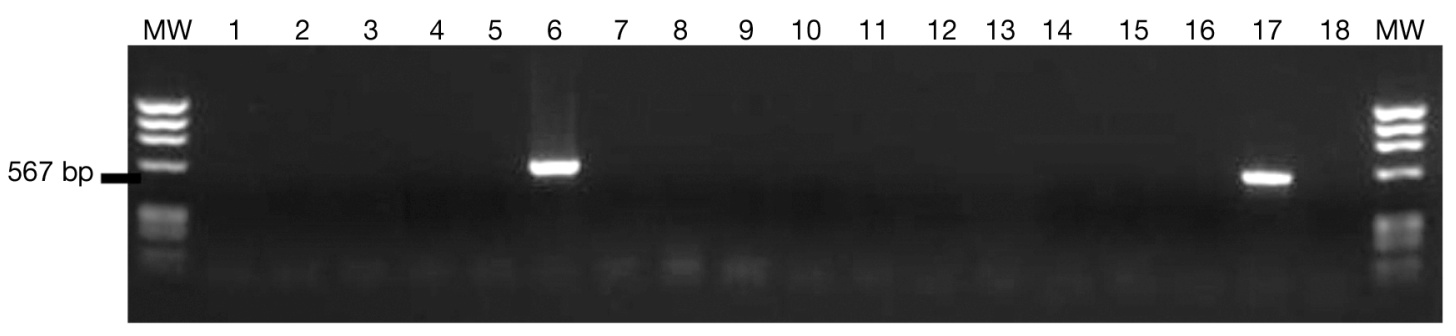

Fig. 2. PCR amplification of the 567 bp dly gene fragment of Photobacterium damselae subsp. damselae strains using dly-5' and dly-3' primers. Lanes: 1: 203H; 2: 401H; 3: 9401H; 4: 412B; 5: 403D1; 6: 402O; $7: 501 \mathrm{H}_{;}$8: 501R; 9: 501B; 10: 601R; 11: 602R; 12: D408U; 13: C501R; 14: S503C; 15: LB501R; 16: LCA907; 17: ATCC 33539T ; 18: Negative control (DNA from P. damselae subsp. piscicida ATCC $17911^{\mathrm{T}}$ ); MW: 72 to 1353 bp ladder 
thermolabile, and it is not associated with their thermoresistant lipopolysaccharide content. Fish inoculated with heat-inactivated ECP samples showed enlarged lymphohematopoietic organs suggesting a stimulation of immune response with cellular accumulation. Rey et al. (2009) reported that ECPs of Aeromonas hydrophila induced larger accumulations of hyaline structures resembling necrotic erythrocytes, into the lymphoid organs compared to the signs induced by the live bacterial cells alone. Hemolysis of erythrocytes in several fish organs has previously been reported during infections with fish pathogenic bacteria (Grizzle \& Kiryu 1993).

Tissue cultures have played a crucial role in investigating bacterial-host interactions due to the easy manipulation of cells and their maintenance under controlled conditions. In the present study, all lethal ECP samples were also cytotoxic both for mammalian and fish cell lines (Fig. 1). The cytotoxicity was totally lost on heated ECP samples, indicating the presence of a thermolabile extracellular cytolysin.

It has been proposed that bacterial peptidases provoke degradation of host tissues, playing an important role in bacterial pathogenesis as they allow the pathogen invasion (Miyoshi \& Shinoda 2000). In addition, peptidases enable the evasion of the bacteria from several fish defense mechanisms (Vivas et al. 2004). In the present study, the proteolytic activities of the Photobacterium damselae subsp. damselae ECPs tested were very low (Table 1), without production of caseinase or gelatinase (Table 2), but they exhibited other activities such as phospholipase, lipase, amylase, phosphatases, or glycosidases (Tables 2 \& 3). Nevertheless, none of these activities could be related with the high degree of toxicity both in vivo and in vitro presented by the ECPs, in contrast to results reported for other fish pathogens (Esteve et al. 1995).

On the other hand, several authors have demonstrated that the pathogenicity of bacterial fish pathogens was related to the capability to hemolyse the host erythrocytes (Borrego et al. 1991, Fouz et al. 1993, Pedersen et al. 2009). The differences found in the hemolytic activity of the Photobacterium damselae subsp. damselae strains (Table 2) are in agreement with the results obtained by Cutter \& Kreger (1990) and Thyssen et al. (1998), who reported variable responses dependent on both the source of the erythrocytes and the strain source. Surprisingly, the hemolytic activity disappeared in the ECPs, except for the strain $402 \mathrm{O}$ (Table 2). A correlation between the hemolytic activity of $P$. damselae subsp. damselae strains and their virulence properties could not also be established.

Fouz et al. (1993) reported that Photobacterium damselae subsp. damselae (formerly Vibrio damsela) strains isolated from diseased fish secreted a cytolysin with phospholipase activity named damselysin, which plays an important role in the virulence mechanism of this pathogen for both fish and mammals. However, in the present study, although $75 \%$ of the virulent strains showed phospholipase activity in their ECPs, only 2 of them (strains $402 \mathrm{O}$ and ATCC 33539 ${ }^{\mathrm{T}}$ ) showed the specific amplicon corresponding to the phospholipaseD (dly) gene (Fig. 2). Similarly, other authors have concluded that not all $P$. damselae subsp. damselae strains carry the dly gene (Clarridge \& Zighelboim-Daum 1985, Osorio et al. 2000). Therefore, a correlation between the presence of dly gene and the pathogenicity of the $P$. damselae subsp. damselae might not be established. Consequently, we can hypothesize that another unknown type of toxin, different to the dly gene, could be involved on the toxicity of the P. damselae subsp. damselae ECPs. A neurotoxin possessing an acetylcholine-esterase activity has been described in strains of Aeromonas hydrophila and several species of Vibrio, including $V$. damsela ( $P$. damselae subsp. damselae), which could be responsible for several clinical signs observed in the present study (Balebona et al. 1998b, Perez et al. 1998).

In conclusion, the cytopathology induced by ECPs in cell lines would be an adequate in vitro model for the determination of Photobacterium damselae subsp. damselae virulence. On the other hand, more efforts would be necessary to demonstrate the neurotoxic effect of $P$. damselae subsp. damselae ECPs by determination of the acetylcholine-esterase activity. In addition, the presence of phospholipases (including damselysin) is not directly related to the pathogenic properties of $P$. damselae subsp. damselae strains.

Acknowledgements. This study was supported in part by the grants RTA2005-00028-C02 from INIA (Subprograma Nacional de Recursos y Tecnologías Agrarias en cooperación con las Comunidades Autónomas), and AGL2006-13208-C02-02, both from the Spanish Government.

\section{LITERATURE CITED}

Bakopoulos V, Adams A, Richards RH (1997) The effect of iron limitation growth conditions on the cell extracellular components of the fish pathogen Pasteurella piscicida. J Fish Dis 20:297-306

Bakopoulos V, Pearson M, Volpatti D, Gousmani L, Adams A, Galeotti M, Dimitriadis GJ (2003) Investigation of media formulations promoting differential antigen expression by Photobacterium damsela ssp. piscicida and recognition by sea bass, Dicentrarchus labrax (L.), immune sera. J Fish Dis 26:1-13

Bakopoulos V, Hanif A, Poulos K, Galeotti M, Adams A, Dimitriadis GJ (2004) The effect of in vivo growth on the cellular and extracellular components of the marine bacterial pathogen Photobacterium damsela ssp. piscicida. J Fish Dis 27:1-13

> Balebona MC, Andreu MJ, Bordas MA, Zorrilla I, Moriñigo MA, Borrego JJ (1998a) Pathogenicity of Vibrio alginolyti- 
cus for cultured gilt-head sea bream (Sparus aurata L.). Appl Environ Microbiol 64:4269-4275

Balebona MC, Krovacek K, Moriñigo MA, Mansson I, Faris A, Borrego JJ (1998b) Neurotoxic effect on two fish species and a PC12 cell line of the supernate of Vibrio alginolyticus and Vibrio anguillarum. Vet Microbiol 63:61-69

> Bejar J, Borrego JJ, Alvarez MC (1997) A continuous cell line from the cultured marine fish gilt-head sea bream (Sparus aurata, L.). Aquaculture 150:143-153

Borrego JJ, Moriñigo MA, Bosca M, Castro D, Martinez-Manzanares E, Barja JL, Toranzo AE (1991) Virulence properties associated with the plasmid content of environmental isolates of Aeromonas hydrophila. J Med Microbiol 35: 264-269

Buck JD, Overstrom NA, Patton GW, Anderson HF, Gorzelany JF (1991) Bacteria associated with stranded cetaceans from the northeast USA and southwest Florida Gulf coasts. Dis Aquat Org 10:147-152

Cardenas S, Manchado M (2008) Perspectives for redbanded seabream culture. Glob Aquaculture Advoc May-June: $56-58$

> Clarridge JE, Zighelboim-Daum S (1985) Isolation and characterization of two haemolytic phenotypes of Vibrio damsela associated with a fatal wound infection. J Clin Microbiol 21:302-306

Coffey JA Jr., Harris RL, Rutledge ML, Bradshaw MW, Williams TW Jr. (1986) Vibrio damsela: another potentially virulent marine vibrio. J Infect Dis 153:800-802

Collado R, Fouz B, Sanjuán E, Amaro C (2000) Effectiveness of different vaccine formulations against vibriosis caused by Vibrio vulnificus serovar E (biotype 2) in European eels Anguilla anguilla. Dis Aquat Org 43:91-101

Cutter DL, Kreger AS (1990) Cloning and expression of the damselysin gene from Vibrio damsela. Infect Immun 58: 266-268

David VA, Deutch AM, Sloma A, Pawlyk D, Ally A, Durham DR (1992) Cloning, sequencing and expression of the gene encoding the extracellular neutral protease, vibriolysin, of Vibrio proteolyticus. Gene 112:107-112

Esteve C, Amaro C, Garay E, Santos Y, Toranzo AE (1995) Pathogenicity of live bacteria and extracellular products of motile Aeromonas isolated from eels. J Appl Bacteriol 78: 555-562

Farto R, Perez MJ, Fernandez-Briera A, Nieto TP (2002) Purification and partial characterization of a fish lethal extracellular protease from Vibrio pelagius. Vet Microbiol 89:181-194

Farto R, Armada SP, Montes M, Perez MJ, Nieto TP (2006) Presence of a lethal protease in the extracellular products of Vibrio splendidus-Vibrio lentus related strains. J Fish Dis 29:701-707

Finkelstein RA, Boesman-Finkelstein M, Chang Y, Hase CC (1992) Vibrio cholerae hemagglutinin/protease, colonial variation, virulence, and detachment. Infect Immun 60: $472-478$

Fouz B, Larsen JL, Toranzo AE (1991) Vibrio damsela as a pathogenic agent causing mortalities in cultured turbot (Scophthalmus maximus). Bull Eur Assoc Fish Pathol 11: 80-81

Fouz B, Larsen JL, Nielsen B, Barja JL, Toranzo AE (1992) Characterization of Vibrio damsela strains isolated from turbot Scophthalmus maximus in Spain. Dis Aquat Org 12: 155-166

> Fouz B, Barja JL, Amaro C, Rivas C, Toranzo AE (1993) Toxicity of the extracellular products of Vibrio damsela isolated from diseased fish. Curr Microbiol 27:341-347

Fouz B, Novoa B, Toranzo AE, Figueras A (1995) Histopatho- logical lesions caused by Vibrio damsela in cultured turbot Scophthalmus maximus (L.) inoculations with live cells and extracellular products. J Fish Dis 18:357-364

Fujioka RS, Greco SB, Cates MB, Schroeder JP (1988) Vibrio damsela from wounds in bottlenose dolphins Tursiops truncatus. Dis Aquat Org 4:1-8

Garcia-Rosado E, Cano I, Martin-Antonio B, Labella A and others (2007) Co-occurrence of viral and bacterial pathogens in disease outbreaks affecting newly cultured sparid fish. Int Microbiol 10:193-199

Grizzle JM, Kiryu Y (1993) Histopathology of gill, liver and pancreas, and serum enzyme levels of channel catfish infected with Aeromonas hydrophila complex. J Aquat Anim Health 5:36-50

Hjeltnes B, Roberts RJ (1993) Vibriosis. In: Inglis V, Roberts RJ, Bromage NR (eds) Bacterial diseases of fish. Halsted Press, New York, NY, p 109-121

Ishihara M, Kawanishi A, Watanabe H, Tomochika K, Miyoshi S, Shinoda S (2002) Purification of a serine protease of Vibrio parahaemolyticus and its characterization. Microbiol Immunol 46:298-303

Kanchanopas-Barnette P, Labella A, Alonso MC, Manchado M, Castro D, Borrego JJ (2009) The first isolation of Photobacterium damselae subsp. damselae from Asian seabass Lates calcarifer. Fish Pathol 44:47-50

Kothary MH, Kreger AS (1985) Purification and characterization of an extracellular cytolysin produced by Vibrio damsela. Infect Immun 49:25-31

> Kreger AS (1984) Cytolytic activity and virulence of Vibrio damsela. Infect Immun 44:326-331

> Kreger AS, Bernheimer AW, Etkin LA, Daniel LW (1987) Phospholipase D activity of Vibrio damsela cytolysin and its interaction with sheep erythrocytes. Infect Immun 55: 3209-3212

Labella A, Vida M, Alonso MC, Infante C and others (2006) First isolation of Photobacterium damselae subsp. damselae from cultured redbanded seabream, Pagrus auriga Valenciennes, in Spain. J Fish Dis 29:175-179

> Labella A, Manchado M, Alonso MC, Castro D, Romalde JL, Borrego JJ (2009) Molecular intraspecific characterization of Photobacterium damselae ssp. damselae affecting cultured marine fish. J Appl Microbiol 108:2122-2132

Lamas J, Santos Y, Bruno D, Toranzo AE, Anadon R (1994) A comparison of pathological changes caused by Vibrio anguillarum and its extracellular products in rainbow trout (Oncorrhynchus mykiss). Fish Pathol 29:79-89

- Liu PV (1957) Survey of haemolysin production among species of Pseudomonas. J Bacteriol 74:718-727

Magariños B, Romalde JL, Lemos ML, Barja JL, Toranzo AE (1994) Iron uptake by Pasteurella piscicida and its role in pathogenicity for fish. Appl Environ Microbiol 60: 2990-2998

Martin-Antonio B, Jimenez-Cantizano RM, Salas-Leiton E, Infante C, Manchado M (2009) Genomic characterization and gene expression analysis of four hepcidin genes in the redbanded seabream (Pagrus auriga). Fish Shellfish Immunol 26:483-491

Miyoshi S, Shinoda S (2000) Microbial metalloproteases and pathogenesis. Microbes Infect 2:91-98

Norqvist A, Norrman B, Wolf-Watz H (1990) Identification and characterization of a zinc metalloprotease associated with invasion by the fish pathogen Vibrio anguillarum. Infect Immun 58:3731-3736

> Osorio CR, Romalde JL, Barja JL, Toranzo AE (2000) Presence of phospholipase-D (dly) gene coding for damselysin production is not a pre-requisite for pathogenicity in Photobacterium damselae subsp. damselae. Microb Pathog 28: 119-126 
Pedersen K, Dalsgaard I, Larsen L (1997) Vibrio damsela associated with diseased fish in Denmark. Appl Environ Microbiol 63:3711-3715

Pedersen K, Skall HF, Lassen-Nielsen AM, Bjerrum L, Olesen NJ (2009) Photobacterium damselae subsp. damselae, an emerging pathogen in Danish rainbow trout, Oncorhynchus mykiss (Walbaum), mariculture. J Fish Dis 32: 465-472

Perez MJ, Rodriguez LA, Nieto TP (1998) The acetylcholinesterase ichthyotoxin is a common component in the extracellular products of Vibrionaceae strains. J Appl Microbiol 84:47-52

Reed LJ, Muench H (1938) A simple method of estimating fifty percent endpoints. Am J Hyg 27:493-497

$>$ Rey A, Verjan N, Ferguson HW, Iregui C (2009) Pathogenesis of Aeromonas hydrophila strain KJ99 infection and its extracellular products in two species of fish. Vet Rec 164: 493-499

Rodkhum C, Hirono I, Crosa JH, Aoki T (2005) Four novel hemolysin genes of Vibrio anguillarum and their virulence to rainbow trout. Microb Pathog 39:109-119

Sakai DK (1985) Significance of extracellular protease for growth of a heterotrophic bacterium, Aeromonas salmonicida. Appl Environ Microbiol 50:1031-1037

Santos Y, Toranzo AE, Barja JL, Nieto TP, Villa TG (1988) Virulence properties and enterotoxin production of Aeromonas strains isolated from fish. Infect Immun 56: 3285-3293

Silva AJ, Pham K, Benitez JA (2003) Haemogglutinin/protease expression and mucin gel penetration in El Tor

Editorial responsibility: David Bruno,

Aberdeen, UK biotype Vibrio cholerae. Microbiology 149:1883-1891

Thune RL, Stanley LA, Cooper K (1993) Pathogenesis of Gram-negative bacterial infections in warm water fish. Annu Rev Fish Dis 3:37-65

Thyssen A, Grisez L, van Houdt R, Ollevier F (1998) Phenotypic characterization of the marine pathogen Photobacterium damselae subsp. piscicida. Int J Syst Bacteriol 48:1145-1151

Toranzo AE, Barja JL (1993) Virulence factors of bacteria pathogenic for coldwater fish. Annu Rev Fish Dis 3:5-36

Vera P, Navas JI, Fouz B (1991) First isolation of Vibrio damsela from seabream (Sparus aurata). Bull Eur Assoc Fish Pathol 11:112-113

- Vivas J, Razquin BE, Lopez-Fierro P, Naharro G, Villena A (2004) Correlation between production of acyl homoserine lactones and proteases in an Aeromonas hydrophila aroA live vaccine. Vet Microbiol 101:167-176

> Wang XH, Oon HL, Ho GWP, Wong WSF, Lim TM, Leung KY (1998) Internalization and cytotoxicity are important virulence mechanisms in vibrio-fish epithelial cell interactions. Microbiology 144:2987-3002

Wang Q, Liu Q, Ma Y, Rui H, Zhang Y (2007) LuxO controls extracellular protease, haemolytic activities and siderophore production in fish pathogen Vibrio alginolyticus. J Appl Microbiol 103:1525-1534

Yamane K, Asato J, Kawade N, Takahashi H, Kimura B, Arakawa Y (2004) Two cases of fatal necrotizing fascitis caused by $P$. damselae in Japan. J Clin Microbiol 42: 1370-1372

Submitted: April 26, 2010; Accepted: August 3, 2010 Proofs received from author(s): October 1, 2010 